\title{
Magmatic sulfide ore deposits
}

Stephen J. Barnes ${ }^{1}$, David A. Holwell ${ }^{2}$ and Margaux Le Vaillant ${ }^{1}$

1 CSIRO Mineral Resources, 26 Dick Perry Avenue, Kensington WA 6151, Australia; Steve.Barnes@csiro.au Margaux.Levaillant@csiro.au

2 Department of Geology, University of Leicester, Leicester, LE1 7RH, United Kingdom; dah29@le.ac.uk

\begin{abstract}
Magmatic sulfide ore deposits are products of natural smelting: concentration of elements from silicate magmas (slags) by immiscible sulfide liquid (matte). Deposits occupy a spectrum from accumulated pools of matte within small igneous intrusions or lava flows, forming orebodies mined primarily for $\mathrm{Ni}$ and $\mathrm{Cu}$, to stratiform layers of weakly disseminated sulfides, mined for platinum group elements, within large maficultramafic intrusions. One of the world's most valuable deposits, the Platreef in the Bushveld Complex in South Africa, has aspects of both of these end members. Natural matte compositions vary widely between and within deposits, controlled largely by the relative volumes of matte and slag that interact with one another.
\end{abstract}

KEYWORDS: nickel, sulfide, platinum, layered intrusions, large igneous provinces, magma, igneous petrology

\section{INTRODUCTION}

Magmatic sulfide deposits are nature's smelters. By the same process that has been used since prehistoric times to extract metals from ores, magmatic sulfide ores form by the interaction between immiscible sulfide-oxide liquids (mattes) with silicate magmas (slags). Scavenging of chalcophile elements - Ni, $\mathrm{Cu}, \mathrm{Au}$ and the platinum group elements (PGE) - and accumulation of the matte component (Figure 1), has produced some of the world's most valuable economic metal concentrations (Naldrett 2004). These currently account for $\sim 56 \%$ of the world's Ni production and over $96 \%$ of supply of Pt, Pd and the other PGE (Mudd and Jowitt 2014). 


\section{Magmatic sulfide deposit settings}

On a deposit scale, magmatic sulfide accumulations are found in a variety of host igneous rock bodies. Broadly they fall into two major categories: sulfide-rich, exploited primarily for $\mathrm{Ni}$ and $\mathrm{Cu}$; and sulfide-poor (typically less than $5 \%$ sulfide) where the dominant value is in the platinum-group elements (PGE) and Au.

Sulfide-rich Ni-Cu dominant deposits can be further categorized:

1. Sulfide-rich accumulations in small mafic or mafic-ultramafic intrusions, (Fig. 1A,B) usually identifiable as magma conduits (Lightfoot and Evans-Lamswood 2015). Important examples include Voisey's Bay (Canada), Jinchuan (China) and the Norilsk-Talnakh deposits, Siberia. With the notable exception of the NorilskTalnakh ores, the PGE are minor by-products.

2. Accumulations of sulfide in komatiites (e.g. the Kambalda and Perseverance deposits in Australia, Barnes 2006), or ferropicrites (e.g. the Pechenga deposits, Russia, Hanski et al. 2011). Deposits are hosted in lava flows (Fig. 2A) or shallow subvolcanic intrusions; exploited dominantly for Ni only.

3. Sulfide accumulation beneath an impact-generated crustal melt sheet: the unique example of the Sudbury Ni-Cu-PGE ores (Keays and Lightfoot 2004).

Sulfide-poor PGE-dominant deposits fall into two types:

1. Stratiform accumulations of a few percent of disseminated sulfide in cumulates within large layered mafic-ultramafic intrusions, including PGE-enriched "reefs" (Naldrett et al. 2008). Such deposits are typically exploited for PGEs with byproduct $\mathrm{Ni}, \mathrm{Cu}$ and $\mathrm{Co}$. They generally occur as remarkably thin and persistent layers: the best-known example, the Merensky Reef of the Bushveld Complex (Figure 1C) is commonly only a few tens of $\mathrm{cm}$ thick but extends continuously for over $400 \mathrm{~km}$.

2. Generally thicker, stratabound sulfide disseminations, commonly PGE-rich, in the marginal rocks of large layered intrusions such as the Platreef, Bushveld Complex (McDonald and Holwell 2011). 


\section{The form of ore-hosting magma bodies}

Stratiform reef-style PGE deposits are exclusively hosted within large sill-like or boatshaped layered mafic-ultramafic intrusions, usually several km thick. The magma bodies that host $\mathrm{Ni}-\mathrm{Cu}$ dominant, sulfide-rich orebodies are more diverse in form (Figure 2). They all represent the products of magma flowing through restricted conduits or channels. These can be feeder tubes or channels within extensive komatiite lava flow fields (Lesher 1989; Barnes 2006) (Fig. 2A), or feeders to large igneous province magmatism in the form of sill-dike combinations (Fig. 2C) or tube-like "chonoliths" (Fig. 2D,E) (Barnes et al. 2015; Lightfoot and Evans-Lamswood 2015). Almost all examples show much higher proportions of sulfide and cumulus silicate minerals (typically olivine) within the flow or intrusion than could have been dissolved in a volume of magma equal to that of the host body, indicating that much larger volumes of magma flowed through the conduit leaving crystals and sulfide liquid behind. Commonly there is evidence of thermal or thermomechanical erosion, in the form of transgressive footwall troughs beneath komatiite flows (Fig. 2A), or in "chonoliths" (Fig. 2D,E) that truncate layering within the country rock and often contain partially digested wall rock fragments. Such host bodies are usually very small compared to the total volume of magmatism in the province: in the case of the ore-hosting intrusions of the Norilsk-Talnakh camp, about 1 millionth of the total volume of the Siberian Trap lavas.

Figure 2. Intrusion geometries...

\section{THE NATURE OF MAGMATIC SULFIDE ORES}

\section{Mineralogy}

Magmatic sulfide ores have a wide range of sulfide contents: from less than a tenth of a percent in some stratiform PGE ores, to pure sulfide in some Ni-Cu deposits (Figure 1).. Almost all unaltered magmatic sulfide ores, regardless of sulfide mode, have a characteristic assemblage of pyrrhotite-pentlandite-chalcopyrite-platinum-group minerals (PGM); an assemblage formed from the cooling and crystallization of a magmatic-derived sulfide matte. Natural mattes, consisting predominantly of $\mathrm{Fe}, \mathrm{Ni}, \mathrm{Cu}$ and $\mathrm{S}$ fractionate to form a sequence of phases on cooling. Below $\sim 1100^{\circ} \mathrm{C},(\mathrm{Ni}, \mathrm{Fe}) \mathrm{S}$ monosulfide solid solution (mss) crystallizes leaving a $\mathrm{Cu}$-rich sulfide liquid enriched in Pt, Pd and semi-metals (e.g. Te, Bi, As). At $\sim 900^{\circ} \mathrm{C}$, the $\mathrm{Cu}$-rich liquid crystallizes to 
intermediate solid solution (iss, approximately $\mathrm{CuFeS}_{2}$ ), leaving a residual melt progressively enriched in Pt, Pd and semi-metals (Li et al. 1996). This fractionation process takes place on scales from that of individual $\sim \mathrm{cm}$ sized globules (Figure 3 ) to entire orebodies, e.g. the supergiant $\mathrm{Cu}-\mathrm{PGE}$ rich Oktyabrysky orebody at Talnakh in Siberia (Torgashin 1994). On further cooling to below $\sim 700^{\circ} \mathrm{C}$, mss breaks down to pyrrhotite and pentlandite, iss to chalcopyrite, and the low-T residual liquid crystallizes Pt and Pd tellurides, bismuthotellurides and arsenides. The common co-occurrence of magnetite arises from the ability of mattes to also dissolve substantial amounts of $\mathrm{FeO}$ (Naldrett, 2004).

Figure 3. Norilsk differentiated bleb

\section{Sulfide Ore Textures and Evidence for Magmatic Origins}

Textural relationships between sulfides and their host silicates are key evidence for their origin (Figure 4). One of the critical textures from a historical point of view is that interpreted by Hawley (1962) as a frozen emulsion of immiscible silicate and sulfide liquids, in one of the first papers to argue persuasively for the primary magmatic origin of the Sudbury ores (Figure 4A). Other diagnostic magmatic features are: (1) net- or matrix textures (Fig. 4B), where sulfides form a continuous 3D matrix enclosing cumulus silicates; (2) interspinifex ores in komatiites (Fig. 4C) where sulfide occupies the original spaces between dendritic olivine plates (Barnes et al. 2016); (3) sub-spherical globular ores, sometime associated with infilled vesicles (Fig. 4D,E); and (4) breccia textures where silicate fragments are disaggregating through melting within a sulfide liquid matrix (Fig. 1B).

\section{Figure 4. Sulfide ore textures.}

\section{ORE FORMING PROCESSES}

The great majority of magmatic sulfide deposits form from much the same sequence of processes: generation of a sulfide-silicate liquid emulsion; physical separation of a mixture of sulfide liquid droplets and cumulus silicate minerals from this emulsion; and deposition and coalescence of sulfide liquid in specific sites. In some cases, the final disposition of the ores is influenced by post-deposition migration of coalesced sulfide liquid pools, driven by the balance between surface tension and gravitational forces (Barnes et al, 2016). 


\section{Generation of sulfide liquids}

This fundamental process can happen by a variety of mechanisms.

Partial melting of sulfide-bearing mantle.

Sulfide liquid can be generated at source where the degree of partial melting is low enough that the sulfide component of the source melts, but does not completely dissolve in the silicate partial melt. The $S$ content of silicate magmas in equilibrium with matte (S content at sulfide liquid saturation, or SCSS) increases with decreasing pressure, such that sulfide-saturated magmas generated in the mantle are likely to be undersaturated on arrival in the upper crust (Edmonds and Mather, 2016, this issue).

Fractional crystallization of silicate magma.

Sulfur behaves as an incompatible element under sulfide-undersaturated conditions, so fractional crystallization causes $S$ content to increase. Sulfide liquation occurs once the $S$ content of the magma exceeds the SCSS, which itself decreases with decreasing temperature and Fe content. Within cumulate sequences, the first onset of sulfide liquid saturation can generate extremely PGE enriched mattes, as in the Platinova Reef of the Skaergaard intrusion (Holwell et al., 2016).

Mixing of two magmas both of which are at or close to sulfide liquid saturation.

This mechanism can give rise to a hybrid magma with transient sulfide supersaturation. This process has been invoked to explain the origin of PGE Reefs associated with major magma influxes in large chambers, such as the Merensky Reef of the Bushveld Complex (Campbell et al. 1983).

Incorporation of external crustal S, giving rise to sulfide "xenomelts".

Addition of external $\mathrm{S}$ is regarded as the dominant process in the formation of all komatiite-hosted ores (Lesher, 1989), and in the great majority of intrusion-hosted deposits (Ripley and Li 2013). Crustal rocks can have S isotope and S/Se ratio signatures that are usually very distinct from mantle $S$, such that these signatures can be used as tracers for orebody S sources. In some cases of deposits where $\mathrm{S}$ isotopic composition is mantle like (e.g. Jinchuan in China; Ripley et al., 2005) the crustal signal may have 
obliterated by high R-factor equilibration with large volumes of magma. A variety of mechanisms exist for incorporation of external S, but direct melting of physically incorporated sulfidic country rock fragments (xenoliths) to form sulfide "xenomelts" is the fastest and most effective (Robertson et al. 2016).

\section{COMPOSITION OF MAGMATIC SULFIDE ORES}

Figure 5. Ore compositions

\section{Variability in Ni and Cu content}

The first order variability in $\mathrm{Ni}$ and $\mathrm{Cu}$ tenors (tenor = concentration of the metal in $100 \%$ sulfide) is related to the composition of the host rocks (Figure 5a). There is a decrease in the Ni:Cu ratio from values around 20:1 in komatiites through 4:1 in ores associated with komatiitic basalts, to between 0.5 and 5:1 in most deposits (both $\mathrm{Ni}$-Cu sulfide-rich type, and reef-style low sulfide PGE type) associated with mafic magmas. Lower Ni:Cu ratios are found in ores where there has been extensive sulfide liquid fractionation, as at Norilsk-Talnakh and in the Sudbury footwall veins (Naldrett et al. 1997) but also in disseminated ores associated with advanced fractionation of tholeiitic mafic magmas. Values of $\mathrm{Ni} / \mathrm{Cu}$ in ores correspond reasonably well with those in the parent magmas themselves (Barnes and Lightfoot, 2005), which for mafic host magmas range from highMg basalts through to fractionated tholeiites. Nickel becomes depleted in more evolved magmas due to olivine crystallization, whereas $\mathrm{Cu}$ becomes enriched due to incompatibility in the major crystallizing silicate phases. Hence, primitive high-T komatiites have very high $\mathrm{Ni}$ and low $\mathrm{Cu}$ compared with more fractionated mafic magmas that attain progressively lower $\mathrm{Ni} / \mathrm{Cu}$. This contrast is reflected in sulfide compositions (Fig. 5A). The most extreme Cu-rich example is the Platinova Reef (PN in Figure 5) of the Skaergaard Intrusion. Here, sulfide saturation occurred very late in the crystallization history, and the magma attained saturation in $\mathrm{Cu}-\mathrm{Fe}$ sulfide liquid rather than the typical Fe-Ni-dominated sulfide (Holwell et al. 2016).

\section{Variability in PGE content}

Platinum group element (PGE) tenors (represented in Figure 5B by Pd) show a much wider range than those of $\mathrm{Ni}$ and $\mathrm{Cu}$. PGE tenors range over nearly 6 orders of magnitude between the most depleted Ni-Cu deposits to the most enriched, Reef-style ores. The PGE tenors correlate broadly with $\mathrm{Ni}$ and $\mathrm{Cu}$ over the komatiite and komatiitic basalt 
associated groups, but much less strongly in deposits associated with dominantly mafic intrusions.

PGE tenors are controlled by two major effects: parent magma compositions, and mass balance effects. The PGE contents of silicate melts in part reflect the variable degree of igneous compatibility of the different PGEs: Ir, Os and Ru are moderately compatible, and Pt and Pd are strongly incompatible. Superimposed on this effect is the very strong tendency of all the PGEs to become strongly depleted during fractional extraction of sulfide liquid, owing to their extreme chalcophile character (Mungall and Brenan 2014). The tendency of mafic magmas to lose PGEs to sulfides either through retention in the mantle during partial melting, or sulfide liquid extraction during ascent, accounts in part for the much wider range in PGE tenors in mafic relative to komatiitic settings; komatiite form by much higher degrees of partial melting and therefore have a much lower susceptibility to sulfide-related PGE extraction at depth (Barnes et al., 2015).

A further control on sulfide liquid compositions is the mass ratio, $\mathrm{R}$, of silicate to sulfide liquid that react with one another (Campbell and Naldrett, 1979). This relationship is expressed as:

$$
Y_{i}^{s u l}=\square X_{i}^{s u l} \square D_{i}^{s u l} \square(1+R) \boxminus /\left(R+D_{i}^{s u l}\right)
$$

where $\mathrm{Y}_{\mathrm{i}}^{\mathrm{sul}}$ is the final concentration of element $\mathrm{i}$ in the sulfide liquid, $\mathrm{X}_{\mathrm{i}}$ sil the initial concentration in the silicate liquid, and $\mathrm{D}_{\mathrm{i}}$ sul is the partition coefficient between sulfide and silicate melt. Formation of magmatic sulfides is treated here as a batch equilibrium process: a batch of sulfide liquid forms and segregates from $\mathrm{R}$ times its mass of silicate melt. The effect of variations in $\mathrm{R}$ is shown on the model curves in Figure 5. Where $\mathrm{R}$ is very low compared with $\mathrm{D}_{\mathrm{i}}$ sul, the tenor of element $\mathrm{i}$ is relatively low and tenor depends almost entirely on $\mathrm{R}$. If $\mathrm{R}$ is large relative to $\mathrm{D}_{\mathrm{i}}$ sul the opposite applies: both silicate and sulfide melt have high metal contents that increase almost linearly with D independently of $\mathrm{R}$. The effect operates in natural systems through the wide range in the partition coefficients for the different chalcophile metals: typically around the low hundreds for $\mathrm{Ni}$, $\sim 1000$ for $\mathrm{Cu}$, and of the order of hundreds of thousands for the PGEs (Kiseeva et al., this volume). Hence the extremely chalcophile PGEs are much more susceptible to R factor effects than $\mathrm{Ni}$ and $\mathrm{Cu}$, as can be seen in the model curves in Figure 5. Nickel and $\mathrm{Cu}$ tenors 
approach maximum values where $\mathrm{R}$ is greater than about 1000, while the PGE tenors continue to increase with increasing $\mathrm{R}$ owing to their extreme $\mathrm{D}$ values. Extremely high silicate /sulfide ratios are necessary to produce the high PGE tenors of Reef-style deposits.

Sulfide liquid differentiation can produce additional variability in the proportion of $\mathrm{Cu}$ to $\mathrm{Ni}$ and of Pt and Pd to Ir, Ru and Os, and is progressively more important in orebodies containing initially higher $\mathrm{Cu}$ contents where the melting range of the sulfide component extends to much lower temperatures. This effect produces dispersion at metre to decimetre scale within orebodies (and at $\mathrm{cm}$ scale in individual droplets as seen in Fig. 3), but in some very large systems differentiation is accompanied by physical migration of residual $\mathrm{Cu}$-rich liquid into veins and fractures. At Sudbury this process generates very high grade $\mathrm{Cu}-\mathrm{PGE}$ orebodies hundreds of metres below the base of the host magma body (Naldrett et al., 1997).

\section{THE PLATREEF: THE PGE RESOURCE OF THE FUTURE}

The giant layered ultramafic-mafic Bushveld Complex, South Africa, hosts over threequarters of the world's PGE resources in three main deposits: the UG2 chromitite, the Merensky Reef and the Platreef. The former two are archetypal stratiform reef deposits, with a few percent of PGE-rich sulfides associated with chromite, and thicknesses of a few centimetres to a few metres. The Platreef, in the northern part of the complex, is a much thicker orebody ( $\sim 10-400 \mathrm{~m})$ emplaced as a series of sills with stratabound disseminated sulfides present in a package of mostly pyroxenites that rest directly on ArchaeanProterozoic country rocks (Figure 6). The PGE tenors (Fig. 5B) overlap with those of the Merensky Reef. The Platreef has been interpreted as the lateral equivalent of the Merensky Reef and as the propagating marginal facies of the Bushveld Complex formed as magma was squeezed out at the edges of the expanding magma chamber (Naldrett et al. 2008). The Platreef is likely to be the main source of future supply of PGE in the coming decades, making it one of the most economically significant of all known magmatic sulfide ore deposits.

The Platreef displays much complexity due to its multi-stage origin (McDonald and Holwell 2011). Mass independent S isotopes and S/Se ratios give evidence that sulfide saturation was initially triggered by a bulk assimilation event, most likely of pyritic shales at depth (Penniston-Dorland et al. 2008). Contaminated magma with a cargo of dispersed 
sulfide liquid droplets was then emplaced higher in the crust, at which point interaction with the diverse range of country rocks resulted in further addition of external $S$, lowering the PGE tenor of the sulfides and modifying isotopic and PGM compositions to different degrees depending on the country rock lithology (McDonald and Holwell 2011).

Recent exploration in the northern limb has identified a much more regularly layered sequence, with traceable stratiform mineralization down dip from the surface outcrop of the Platreef, with the addition of thick underlying ultramafic cumulates. This "Flatreef" sequence has many similarities to the Merensky Reef in the rest of the complex, and represents a transition from stratabound 'contact-type' or 'marginal' styles, to stratiform, reef-style mineralization.

Figure 6. Block model of the northern limb of the Bushveld complex.....

\section{THE ELEPHANT IN THE SHIELD: SUDBURY}

No review of magmatic sulfide ores could ignore the world's largest known accumulation of magmatic ores, the extraordinary Sudbury impact structure in the southern part of the Canadian Shield, Ontario. In this case, ore formation followed wholesale melting of almost the entire thickness of the crust following a giant bolide impact (Mungall et al 2004). Sulfide liquid segregated from the resulting melt sheet on subsequent cooling. While many aspects of Sudbury ore genesis are unique, one aspect is highly significant to understanding processes in other deposits: the presence of extensively mobilized veins and dikes of sulfide rich rocks that extend for distances of kilometers below the original base of the melt sheet. These features attest to the extreme physical mobility of sulfide magmas, or possibly sulfide-rich melt emulsions charged with rock fragments, driven by gravity into fracture systems. This is an important clue to the origin of late stage injections of sulfide-rich breccia-textured ores, common in many intrusion hosted deposits (Barnes et al., 2016).

\section{RESEARCH QUESTIONS}

Research in magmatic sulfides has made substantial advances over the five decades from the pioneering work of Naldrett and others, particularly in understanding geochemical processes, but a number of fundamental questions remain about physical processes of ore formation. 
1. Is the addition of external S through assimilation of crustal rocks essential, and by what mechanisms does this addition take place?

2. How is sulfide liquid transported in magmas, in what proportions and in what physical form? How far can sulfide liquids be transported from the original site of liquation to the point of deposition?

3. What is the physical process of deposition, and to what extent is it governed by mechanical sedimentation versus in-situ chemical deposition of sulfide liquid at the point of nucleation?

Magmatic sulfides continue to be fascinating topics of research, leading to advances in exploration models as well as new insights into magmatic and even climatic processes. Applications have been made to meteoritics, in studies of the origin of planetary cores, and into processes of metal and S transport with implications for the origin of porphyry deposits and climate-impacting giant eruptions (Mungall et al. 2015).

\section{ACKNOWLEDMENTS}

We thank Kate Kiseeva and the Elements editorial team for the kind invitation to contribute to this volume. Anais Pages and Angus MacFarlane reviewed a preliminary draft. Elements reviews by Tony Naldrett, Ed Ripley and Vera Lorenz greatly improved the clarity of the manuscript. SJB and MLV acknowledge support from the CSIRO Science Leader program. We acknowledge colleagues too numerous to mention who have contributed data and insights drawn on here.

\section{REFERENCES}

Barnes Sarah-J, Lightfoot PC (2005) Formation of magmatic nickel sulfide deposits and processes affecting their copper and platinum group element contents. Econ Geol 100th Anniversary Volume:179-214

Barnes SJ (2006) Komatiite-hosted nickel sulfide deposits: geology, geochemistry, and genesis. Soc Econ Geologists Spec Pub 13:51-118

Barnes SJ, Cruden AR, Arndt NT, Saumur BM (2016) The mineral system approach applied to magmatic Ni-Cu-PGE sulphide deposits. Ore Geol Rev 76:296-316 doi:10.1016/j.oregeorev.2015.06.012 
Barnes SJ, Mungall JE, Le Vaillant M, Godel B, Lesher CM, Holwell DA, Lightfoot PC, Krivolutskaya NA, Wei B (2016) Sulfide-silicate textures in magmatic Ni-Cu-PGE sulfide ore deposits. 1. Disseminated and net-textured ores. Amer Mineral in review

Barnes SJ, Mungall JE, Maier WD (2015) Platinum group elements in mantle melts and mantle samples. Lithos 232:395-417

Campbell IH, Naldrett AJ (1979) The influence of silicate:sulphide ratios on the geochemistry of magmatic sulphides. Econ Geol 74:1503-1506

Campbell IH, Naldrett AJ, Barnes SJ (1983) A model for the origin of the platinum-rich sulfide horizons in the Bushveld and Stillwater Complexes. J Petrol 24:133-165

Edmonds M, Mather TA (2017) Volcanic sulfides and outgassing. Elements, this issue

Hanski E, Luo Z-Y, Oduro H, Walker RJ (2011) The Pechenga Ni-Cu Sulfide Deposits, Northwestern Russia: A Review with New Constraints from the Feeder Dikes. Rev Econ Geol 17:145-162

Hawley J (1962) The Sudbury ores, their mineralogy and origin; Part 1, The geological setting, . Canadian Mineralogist 7:1-29

Holwell DA, Barnes SJ, Le Vaillant M, Keays RR, Fisher L, Prosser R (2016) 3D textural evidence for the formation of ultra-high tenor precious metal bearing sulfide microdroplets in offset reefs: an extreme example from the Platinova Reef, Skaergaard Intrusion, Greenland. Lithos online doi:10.1016/j.lithos.2016.03.020

Keays RR, Lightfoot PC (2004) Formation of Ni-Cu-platinum group element sulfide mineralization in the Sudbury impact melt sheet. Mineral Petrol 82:217-258

Kiseeva ES, Fonseca ROC, Smythe DJ (2017) Sulfides in the upper mantle: controls over the chalcophile element budget in magmatic systems. Elements, this issue

Lesher CM (1989) Komatiite-associated nickel sulfide deposits. In: Whitney JA, Naldrett AJ (eds) Ore Deposition Associated with Magmas, vol 4. Economic Geology Publishing Company, El Paso, pp 44-101

Li C, Barnes Sarah-J, Makovicky E, Rose-Hansen J, Makovicky M (1996) Partitioning of Ni, Cu, Ir, $\mathrm{Rh}, \mathrm{Pt}$ and Pd between monosulfide solid solution and sulfide liquid: Effects of composition and temperature. Geochim Cosmochim Acta 60:1231-1238

Lightfoot PC, Evans-Lamswood DM (2015) Structural controls on the primary distribution of mafic-ultramafic intrusions containing $\mathrm{Ni}-\mathrm{Cu}-\mathrm{Co}-(\mathrm{PGE})$ sulfide mineralization in the roots of large igneous provinces. Ore Geol Rev 64:354-386

Mavrogenes JA, O'Neill HSC (1999) The relative effects of pressure, temperature and oxygen fugacity on the solubility of sulfide in mafic magmas. Geochimica Et Cosmochimica Acta 63:1173- 1180

McDonald I, Holwell D (2011) Geology of the northern Bushveld Complex and the setting and genesis of the Platreef Ni-Cu-PGE deposit. Magmatic Ni-Cu and PGE deposits: geology, geochemistry, and genesis Rev Econ Geol 17:297-327

Mudd GM, Jowitt SM (2014) A Detailed Assessment of Global Nickel Resource Trends and Endowments. Econ Geol 109:1813-1841

Mungall JE, Brenan JM (2014) Partitioning of platinum-group elements and Au between sulfide liquid and basalt and the origins of mantle-crust fractionation of the chalcophile elements. Geochim Cosmochim Acta 125:265-289 doi:10.1016/j.gca.2013.10.002

Mungall JE, Brenan JM, Godel B, Barnes SJ, Gailard F (2015) Transport of S, Cu and Au in magmas by flotation of sulphide melt on vapour bubbles. Nature Geosci 8:216-219 doi:doi:10.1038/ngeo2373 
Naldrett AJ (2004) Magmatic sulphide deposits. Oxford University Press, New York

Naldrett AJ, Ebel DS, Asif M, Morrison G, Moore CM (1997) Fractional crystallization of sulfide melts as illustrated at Noril'sk and Sudbury. European J Mineral 9(2):365-377

Naldrett AJ, Kinnaird JA, Wilson AH, Chunnett G (2008) Concentration of PGE in the Earth's crust with special reference to the Bushveld Complex. Earth Science Frontiers 15:264-297

Penniston-Dorland SC, Wing BA, Nex PAM, Kinnaird JA, Farquhar J, Brown M, Sharman ER (2008) Multiple sulfur isotopes reveal a magmatic origin for the Platreef platinum group element deposit, Bushveld Complex, South Africa. Geology 36(12):979-982

Ripley EM, Li C (2013) Sulfide saturation in mafic magmas; is external sulfur required for magmatic Ni-Cu-(PGE) ore genesis? Econ Geol 108(1):45-58 doi:http://dx.doi.org/10.2113/econgeo.108.1.45

Ripley EM, Sarkar A, Li CS (2005) Mineralogic and Stable Isotope Studies of Hydrothermal Alteration at the Jinchuan Ni-Cu Deposit, China. Econ Geol 100(7):1349-1361

Robertson JC, Barnes SJ, Le Vaillant M (2016) Dynamics of magmatic sulphide droplets during transport in silicate melts and implications for magmatic sulphide ore formation. J Petrol 56:2445-2472 doi:10.1093/petrology/egv078

Torgashin AS (1994) Geology of the Massive and Copper Ores of the Western Part of the Oktyabr'sky Deposit. In: Lightfoot PC, Naldrett AJ (eds) Proceedings of the SudburyNoril'sk Symposium Ontario Geological Survey Special Publication 5, vol 5. Ontario Geological Survey, Toronto, ON, pp 231-260 